\section{Divisions}

\section{Optics Division}

The invitation of the European Physical Society to the European Optics Committee that it should be reconstituted as a Division of EPS has now been accepted and the members of the provisional Board are given below.

The Optics Division is thus the eighth Division in the Society and both existing and new Individual Members are invited to join by indicating their wish to the EPS Secretariat in Geneva. Elections to the Board will be held after a suitable preparatory period.

Provisional Board

Ch. A. Maréchal, Institute of Optics, Orsay Members:

J. Bescos, Optics Institute, Madrid

J. Bulabois, Franche-Comté University, Besançon

J.A. Ferwerda, State University, Groningen

R. Hamalainen, University, Joensuu

E. Inglestam, Inst. of Optical Research, Stockholm

R. Rohler, Inst. for Medical Optics, Munich

H. Tiziani, Inst. for Technical Optics, Stuttgart W.T. Welford, Blackett Lab., Imp. Coll., London

At its meeting on 12 November the Executive Committee approved the following changes to the Boards of Divisions and Sections.

\section{Atomic Spectroscopy Section (EGAS)}

( $A$ \& $A D$ )

Ch. A.P. Thorne

Physics Dept., Imperial College

Prince Consort Rd., London SW7

The Assembly of members held in Liège elected unopposed two new Board members:

J. Desesquelles, Lyon

G. von Oppen, Berlin

Quantum Electronics Division

Ch. B. Bölger

Philips' Research Laboratories

NL - 5600 JA Eindhoven

The new Secretary to replace R. Dändliker will be announced shortly.

\title{
Official Announcement
}

In view of the increased number of Associate Members, the importance of their contributions to the finances of EPS and the fact that the majority of students who receive a higher education in physics and who remain in physics will be employed in industry, the Executive Council has concluded that a specific representation of the Associate Members in Council would be appropriate. In consequence, Council will be invited at its meeting in Copenhagen, 24-25 March, 1983 to approve the following:

In accordance with the provisions of Article 26 of the Constitution, the Council agrees that Article 16 should be amended by the addition set out below:

d) delegates or representatives elected in accordance with the by-laws, by Associate Members mentioned in Article 6, as follows:

less than 50 Associate Members: 3 representatives

50-100 Associate Members: 4 representatives

100-150 Associate Members: 5 representatives

The Executive Committee considers that the existing policy regarding the voting when the motion before Council is for a change in membership fees should continue, and will invite Council to approve the following amendment to Rule 34 :

The third paragraph shall read:

The Divisional Chairmen and the representatives of Associate Members have no voting right for a change in the value of the unit fee.

The present Associate Members (and the national societies) are being consulted as to the optimum method of electing their representatives; modifications to the appropriate Rules will be tabled at the Council meeting.

It is, in any case, logical that the Rules governing admission and rights of Honorary Members and Associate Members be separated. Council will therefore be invited to amend Rule 4 to read:

Honorary Members shall have the same right as Ordinary Members to attend meetings and subscribe to the publications of the Society. They shall not have the right to vote and they shall not be eligible for service on the Council. Admission to Honorary Membership shall be decided by the Council. The total number of Honorary Members at any one time shall not exceed fifty. and Rule 5 to read:

Associate Members shall have the same right as Ordinary Members to attend meetings and subscribe to the publications of the Society. They shall be represented in Council according to Article $16 \mathrm{~d}$ ) of the Constitution. Admission to Associate Membership shall be decided by the Council.

Computational Physics Group

Ch. G. Diercksen

Max-Planck-Institut für Astrophysik

Fuhringer Ring 6, D - 8000 Munich 40

Sec. P. Van Binst

University of Brussels II HE

2. Ave de la Plaine, B - 1050 Brussels

And to all our readers a Very Happy New Year.

\section{ESO's New Telescope}

The special admission fee, due from Italy and Switzerland since they joined ESO earlier in the year, is to be used to construct another large telescope at ESO's observatory at La Silla in Chile. Costing about DM $30 \mathrm{M}$, the 'New Technology Telescope' will have a $3.5 \mathrm{~m}$ mirror that is highly curved and of light construction, and will be built to a design radically different from traditional practice.
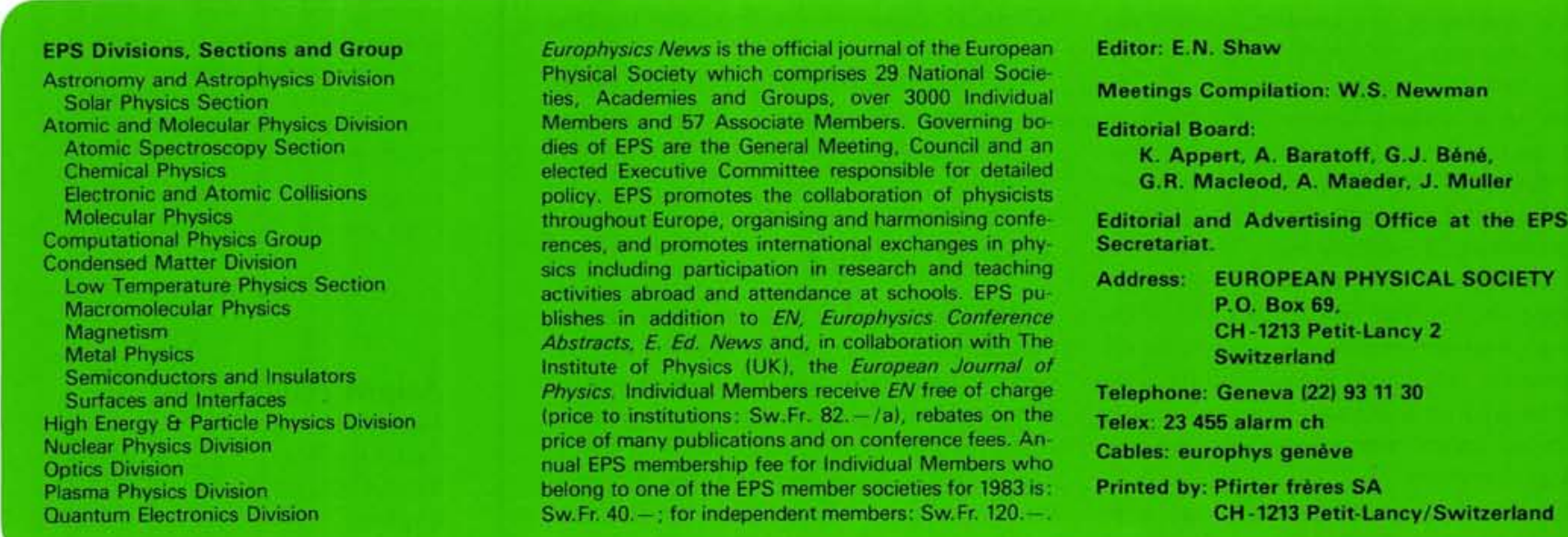